\title{
TUGAS DAN FUNGSI KEPOLISIAN UNTUK MENINGKATKAN KEPERCAYAAN PUBLIK TERHADAP PENEGAK HUKUM
}

\author{
Oleh : \\ Elvi Alfian*
}

\begin{abstract}
ABSTRAK
Tugas pokok dan fungsi Polri, selain sebagai pengayom masyarakat juga sebagai penegak hukum. Tingkat kepercayaan masyarakat terhadap penegakan hukum di negri ini dari hari ke hari grafiknya terus mengalami penurunan. Tingkat ketidak puasan masyarakat terhadap penegakan hukum di negri ini semakin meningkat, hal ini dapat terlihat dengan jelas dari hasil survei yang dilakukan. Dan yang terpenting adalah bagaimana Polri dalam melaksanakan tugas dan fungsinya dengan baik sehingga dapat diterima oleh masyarakat sehingga dapat menjaga keamanan dan ketertiban dengan memperoleh dukungan maksimal dari masyarakatTujuan penelitian ini untuk Untuk menganalisa bagaimana tugas dan fungsi kepolisian untuk meningkatkan kepercayaan publik terhadap penegak hukum dan Untuk menganalisa apa yang menjadi faktor penghambat bagi kepolisian untuk menjalankan tugas dan fungsinya sebagai penegak hukum untuk meningkatkan kepercayaan publik. Penelitian hukum normatif (normative law research) menggunakan studi kasus normatif berupa produk perilaku hukum, misalnya mengkaji undang- undang. Hasil penelitian menunjukkan bahwa : 1.Tugas dan Fungsi Kepolisian Sebagai Penegak Hukum Menurut UU Nomor 2 Tahun 2002 tentang Kepolisian Negara Republik Indonesia dapat dilihat pada Pasal 2 UU No. 2 Tahun 2002 mengenai fungsi Kepolisian. Fungsi kepolisian adalah "salah satu fungsi pemerintahan negara di bidang pemeliharaan kemanan dan ketertiban masyarakat, penegak hukum, perlindungan, pengayoman, dan pelayanan kepada masyarakat. Faktor penghambat kepolisian dalam melaksanakan tugasnya dalam penegakan hukum yaitu : a. Faktor hukumnya sendiri; b.Faktor penegak hukum, yaitu pihak- pihak yang membentuk maupun menerapkan hukum; c.Faktor sarana atau fasilitas; d.Faktor masyarakat, yaitu lingkungan dimana hukum terasebut berlaku atau diterapkan; e. Faktor kebudayaan, yaitu sebagai hasil karya, cipta dan rasa yang didasarkan pada karsa manusia dalam pergaulan hidup..
\end{abstract}

Kata Kunci: Tugas, Fungsi, Kepolisian, Kepercayaan publik, Penegak Hukum

\section{A. Latar Belakang}

Indonesia hampir 15 tahun reformasi telah dijalani oleh bangsa Indonesia berbagai upaya perubahan terus dilakukan baik dalam kebijakan ekonomi, politik, sosial, budaya dan juga reformasi di bidang hukum namun masih saja tujuan reformasi belum mampu terwujud. Dari sekian agenda reformasi yang paling menyedihkan adalah kegagalan di bidang reformasi hukum khususnya dalam penegakan hukum di negeri ini.

Tingkat kepercayaan masyarakat terhadap penegakan hukum di negri ini dari hari ke hari grafiknya terus mengalami penurunan. Tingkat ketidak puasan masyarakat terhadap penegakan hukum di negri ini semakin meningkat, hal ini dapat terlihat dengan jelas dari hasil

\footnotetext{
* Pengajar Fakultas Syariah UIN STS Jambi
} 
survei yang dilakukan Lembaga Survei Indonesia ${ }^{1}$ yang menempatkan tingkat ketidak percayaan publik terhadap penegakan hukum saat ini berada pada angka 56 persen dan hanya 29,8 persen yang menyatakan puas, jika dibandingkan dengan pemerintahan sebelumnya hanya 22,6 persen yang mengatakan penegakan hukum di era pemerintahan sekarang ini lebih baik dari pemerintahan sebelumnya.

Tugas pokok dan fungsi Polri, selain sebagai pengayom masyarakat juga sebagai penegak hukum. Fungsi tersebut merupakan sebagian dari implementasi Pasal 1 ayat (5) UU Nomor 2 Tahun 2002 tentang Kepolisian Negara Republik Indonesia menetapkan bahwa:

Keamanan dan ketertiban masyarakat adalah suatu kondisi dinamis masyarakat sebagai salah satu prasyarat terselenggaranya proses pembangunan nasional yang ditandai oleh terjaminnya tertib dan tegaknya hukum serta terbinanya ketentraman yang mengandung kemampuan membina serta mengembangkan potensi dan kekuatan masyarakat dalam menangkal, mencegah, dan menanggulangi segala bentuk pelanggaran hukum dan bentuk- bentuk gangguan lainnya dapat meresahkan masyarakat.

Sejalan dengan hal tersebut, Soerjono Soekanto ${ }^{2}$ berpendapat bahwa: "hukum dan penegak hukum merupakan sebagian faktor penegakan hukum yang tidak bisa diabaikan, jika diabaikan akan menyebabkan tidak tercapainya penegakan hukum yang diharapkan”. Penegakan hukum, penjagaan keamanan dan ketertiban masyarakat (Kamtibmas) serta pelayanan dan pengayoman masyarakat adalah tugas pokok polisi sebagai profesi mulia, yang aplikasinya harus berdasarkan undang-undang yang berlaku dan hak azasi manusia. Atau dengan kata lain harus bertindak secara professional dan memegang kode etik secara ketat dan keras, sehingga tidak terjerumus kedalam prilaku yang dibenci masyarakat .

Masyarakat dan polisi merupakan dua kegiatan yang tidak bisa di pisahkan. Tanpa masyarakat, tidak akan ada polisi dan tanpa polisi, proses-proses dalam masyarakat tidak akan berjalan dengan lancar dan produktif. Kenyataan tersebut di atas, menurut Barda Nawawi Arief $^{3}$, bahwa Polri dalam menjalankan tugasnya berperan ganda baik sebagai penegak hukum maupun sebagai pekerja sosial (sosial worker) pada aspek sosial dan kemasyarakatan (pelayanan dan pengabdian). Prilaku masyarakat dan penegak hukum menurut Soerjono Soekanto ${ }^{4}$ berpendapat bahwa :

${ }^{1}$ LSI tangkap ketidak puasan rakyat atas penegak hokum: "Sindonews.com Senin 8April 2019 00:32". Menurut Dewi survey dilakukan 1 s/d 4 April 2019

${ }^{2}$ Soerjono Soekanto, Faktor-faktor yang Mempengaruhi Penegakan Hukum, Cet Kelima, Rajawali, Jakarta, 2004, hal., 5.

5.

${ }^{3}$ Barda Nawawi, Bunga Rampai Kebijakan Hukum Pidana, PT. Citra Aditya Bakti, Bandung, 2005, hal.,

${ }^{4}$ Soerjono Soekanto, Efektivitas Hukum Dan Peranan Sanksi, Remaja Karya, Bandung, 2005, hal 10. 
Salah satu fungsi hukum baik sebagai kaidah maupun sebagai sikap tindak atau perilaku teratur adalah membimbing perilaku manusia. Masalah pengaruh hukum tidak hanya terbatas pada timbulnya ketaatan atau kepatuhan pada hukum, tapi mencakup efek total dari hukum terhadap sikap tindak atau prilaku baik yang bersifat positif maupun negatif.

Pembaharuan Undang-undang Kepolisian Indonesia, UU No. 2 Tahun 2002 dimaksudkan untuk lebih memantapkan kedudukan dan peran Polri sebagai fungsi pemerintahan meliputi pemeliharaan keamanan dan ketertiban masyarakat, penegakan hukum, perlindungan dan pengayoman dan pelayanan kepada masyarakat yang menjunjung tinggi hak asasi manusia, harus bebas dari pengaruh kekuasaan pihak manapun, yakni yang dilaksanakan secara merdeka terlepas dari pengaruh kekuasaan pemerintah dan pengaruh kekuasaan lainnya.

Dalam kurun waktu 3 tahun terakhir prosentase tingkat ketidak puasan masyarakat terhadap penegakan hukum di negri ini terus mengalami kenaikan yang cukup signifikan Januari 2015, 37,4 persen, Oktober 2016 41,2, September 2017, 50,3 persen, Oktober 2018, 50,3 dan yang terakhir April 2019, sungguh mengejutkan mencapai 56,0 persen. Dan yang paling mencengangkan ternyata masyarakat di desa justru tingkat ketidakpuasannya mencapai pada angka 61,1 persen sementara di kota mencapai 48,6 persen.

Namun ditengah persepsi minim terhadap kinerja Polri, "masih ada harapan public" terhadap garda depan keamanan rakya tersebut. Sebagian public masih menilai positif kinerja Polri dalam mewujudkan brata ketiga dalam kapasitas sebagai pengayom, pelindung, dan pelayan masyarakat. ${ }^{5}$ Hal itu digambarkan:

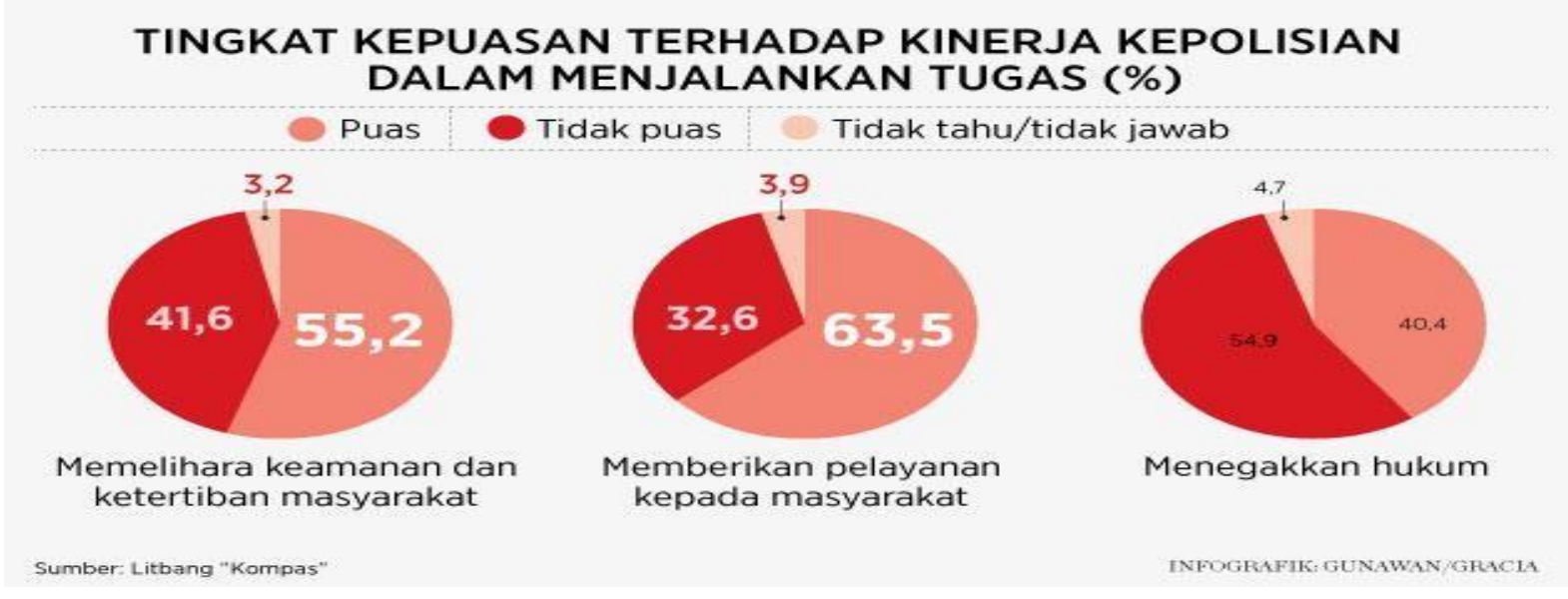

Berdasarkan latar belakang di atas, maka perlu dilakukan penelitian tentang bagaimana tugas dan fungsi penegak hukum, yaitu kepolisian untuk meningkatkan kepercayaan publik terhadap penegak hukum

\footnotetext{
${ }^{5}$ KOMPAS, Senin, 13 April 2019, "Politik \& Jukum" hal. 5
} 


\section{B. Tujuan Penulisan}

Tujuan yang diharapkan dalam penulisan ini adalah

a. Untuk menganalisa tugas dan fungsi kepolisian untuk meningkatkan kepercayaan publik terhadap penegak hukum

b. Untuk menganalisa yang menjadi faktor penghambat bagi kepolisian untuk menjalankan tugas dan fungsinya sebagai penegak hukum untuk meningkatkan kepercayaan publik

\section{Metode Penulisan}

Penulis memutuskan menggunakan metode penelitian hukum normatif untuk meneliti dan menulis pembahasan ini. Penggunaan metode penelitian normatif dalam upaya penelitian dan penulisan skripsi ini dilatari kesesuaian teori dengan metode penelitian yang dibutuhkan penulis. Metode pendekatan dalam penelitian ini adalah pendekatan peraturan perundang-undangan (statue aproach). ${ }^{6}$ Suatu penelitian normatif tentu harus menggunakan pendekatan perundang-undangan, karena yang akan diteliti adalah berbagai aturan hukum yang menjadi fokus sekaligus tema sentral suatu penelitian.

\section{Pembahasan}

\section{Tugas Dan Fungsi Kepolisian Untuk Meningkatkan Kepercayaan Publik Terhadap Penegak Hukum \\ Pengertian Polisi Dan Penegakan Hukum}

Menurut Soebroto Brotodiredjo ${ }^{7}$, istilah polisi berasal dari istilah Yunani Kuno "politeia" yang berarti pemerintahan suatu polis atau kota. W.J.S. Poerwadarminta, ${ }^{8}$ memberikan arti pada kata polisi sebagai badan pemerintahan yang bertugas memelihara keamanan dan ketertiban umum seperti menangkap orang yang melanggar undang-undang atau pegawai negara yang bertugas menjaga keamanan.

Menurut Pasal 5 ayat (1) UU No. 2 Tahun 2002 :

"Kepolisian Negara Republik Indonesia merupakan alat negara yang berperan dalam memelihara keamanan dan ketertiban masyarakat, menegakkan hukum, serta memberikan perlingdungan, pengayoman, dan pelayanan kepada masyarakat dalam rangka terpeliharanya keamanan dalam negeri”.

\footnotetext{
${ }^{6}$ Peter Mahmud Marzuki. 2008.Penelitian Hukum. Cet 2. Jakarta: Kencana. Hal 29

${ }^{7}$ Soebroto Brotodirejo, Polri Sebagai Penegak Hukum, Sespimpol. Bandung,1989, hal.,2

${ }_{8}^{7}$ W.J.S.Poerwadarminta, Kamus Umum Bahasa Indonesia, PN Balai Pustaka, Jakarta, 1985, hal., 763.
} 


\section{Peran dan Fungsi Polri}

Polri sebagai agen penegak hukum dan pembina keamanan dan ketertiban masyarakat. Konsepsi tugas, fungsi dan peran Polri yang bersumber dari landasan yang masih relevan namun masih perlu diorintasikan dengan perkembangan masyarakat. Polri dengan keberadaannya membawa empat peran strategis, yakni:

1. Perlindungan masyarakat;

2. Penegakan Hukum;

3. Pencegahan pelanggaran hukum;

4. Pembinaan Keamanan dan Ketertiban masyarakat.

Sebagaimana diatur'dalam ketentuan UU No. 2 Tahun 2002 tentang Polri secara gamblang dirumuskan bahwa tugas pokok Polri adalah penegak hukum, pelindung, pengayom dan pembimbing masayarakat terutama dalam rangka kepatuhan dan ketaatan pada hukum yang berlaku.

Dalam ketentuan Undang-undang tersebut, ada dua hal yang mendasar tugas utama Polri sebagaimana yang termuat dalam Tribrata maupun Catur Prasetya Polri. Sebagaimana diatur dalam UU No. 2 Tahun 2002, khususnya pada Pasal 13. Dalam ketentuan Pasal 13 ditegaskan bahwa Polri bertugas:

a. memelihara keamanan dan ketertiban masyarakat;

b. menegakkan hukum; dan

c. memberikan perlindungan, pengayoman dan pelayanan kepada masyarakat.

Oleh Satjipto Rahardjo ${ }^{9}$ sebagai penegakan hukum (Law Enforceman Officer) dan pemulihan ketertiban (Order maintenance).

Pelayanan kepada masyarakat (publik), semaksimal mungkin diarahkan untuk tercapainya kondisi yang ideal sebagaimana diamanatkan dalam Tribata yang merupakan pedoman hidup anggota Polri dan Catur Prasetya sebagai pedoman kerja Polri, dimana apabila hal tersebut terlaksana dengan baik dipastikan akan terwujud pelayanan publik yang prima sesuai bidang pelayanan yang diemban Polri.

\section{Penegakan Hukum}

${ }^{9}$ Satjipto Rahardjo, Penyelenggaraan Keadilan Dalam Masyarakat Yang Sedang Berubah, Masalah- Masalah Hukum, Nomor 1-6 Tahun X/10 hal., 20 
Penegakan hukum merupakan suatu proses untuk mewujudkan keinginan- keinginan dalam hukum agar menjadi kewajiban dan ditaati oleh masyarakat ${ }^{10}$.

Secara konseptual menurut Soerjono Soekanto ${ }^{11}$,

"penegakan hukum terletak pada kegiatan menyerasikan hubungan nilai- nilai yang dijabarkan di dalam kaedah- kaedah yang mantap dan mengejawantah serta sikap tindak sebagai rangkaian penjabaran nilai akhir dan untuk menciptakan, memelihara dan mempertahankan pergaulan hidup. Penegakan hukum tidak bisa terlepas dari hak asasi manusia, namun dengan adanya alat-alat paksa khusus (bijzonder dwangmiddelen) yang dimaksud alat paksa disini bukan merupakan pemaksaan fisik melainkan alat pemaksa yang sah diatur oleh ketentuan perundang- undangan seperti penangkapan, penahanan dan penyitaan".

Menurut C.S.T Kansil ${ }^{12}$ sekurang- kurangnya ada 3 (tiga) konsep hukum yang pernah ditemukan orang yaitu :

1. Hukum sebagai asas moralitas atau asas keadilan yang bernilai universal dan menjadi bagian inheren sistem hukum alam

2. Hukum sebagai kaidah-kaidah positif yang berlaku pada suatu waktu tertentu dan tempat tertentu dan terkait sebagai produk eksplisit suatu sumber kekuasaan

3. Hukum sebagai institusi sosial yang riil dan fungsional di dalam proses-proses pengarahan dan pembentukan pola-pola perilaku yang baru.

Penegakan hukum menurut Liliana Tedjosaputro ${ }^{13}$ adalah suatu proses untuk mewujudkan keinginan-keinginan hukum menjadi kenyataan. Keinginan-keinginan hukum disini adalah pikiran-pikiran badan pembuat undang-undang yang dirumuskan dalam peraturan perundang-undangan hukum itu, dan ini akan turut menentukan bagaimana penegakan hukum itu dijalankan.

\section{Tugas dan Fungsi Kepolisian Sebagai Penegak Hukum}

Menurut UU Nomor 2 Tahun 2002 tentang Kepolisian Negara Republik Indonesia Istilah Penegak Hukum (law enforcement officer) yang dalam arti sempit hanya berarti Polisi tetapi dapat juga mencakup Jaksa. Akan tetapi di Indonesia biasanya diperluas pula dengan para Hakim dan ada kecenderungan kuat memasukkan pula dalam pengertian penegak hukum

\footnotetext{
Jakarta,

${ }^{10}$ Baringbing Simpul, RE, Mewujudkan Supremasi Hukum, Pusat Kegiatan Reformasi,

2001, hal., 55.

${ }^{11}$ Seorjono Soekanto, Hukum Acara Pidana, Badan Penerbit Universitas Diponegoro, Semarang, 2006, hal., 7. hal., 12.

${ }^{12}$ Kansil. C.S.T, Pengantar Ilmu Hukum dan Tata Hukum Indonesia, Balai Pustaka, Jakarta, 1992 ,

13 Liliana Tedjosaputro, Etika Profesi Notaris; Penegakan Hukum, PT Bayu Indra Grafika, Yogyakarta, 1995, hal., 55
} 
ini adalah Pengacara (advokat). Dalam pengertian luas terakhir ini, dapat dipergunakan terjemahan dari rechthandhaving, yang artinya penegakkan hukum. Secara konsepsional, maka inti dan arti penegakkan hukum terletak pada kegiatan menyerasikan nilai-nilai yang terjabarkan di dalam kaidah-kaidah yang mantap dan mengejawantah dan sikap tindak sebagai rangkaian penjabaran nilai tahap akhir, untuk menciptakan, memelihara dan mempertahankan kedamaian pergaulan hidup.

Peranan Polri menurut Pasal 1 ayat (5) UU No. 2 Tahun 2002 tentang Kepolisian Negara Republik Indonesia yaitu:

"keamanan dan ketertiban masyarakat adalah suatu kondisi dinamis masyarakat sebagai salah satu prasyarat terselenggaranya proses pembangunan nasional yang ditandai oleh terjaminnya tertib dan tegaknya hukum serta terbinanya ketentraman yang mengandung kemampuan membina serta mengembangkan potensi dan kekuatan masyarakat dalam menangkal, mencegah, dan menanggulangi segala bentuk pelanggaran hukum dan bentuk-bentuk gangguan lainnya dapat meresahkan masyarakat'

Peranan Polri yang diuraikan di atas adalah sejalan dengan fungsi Kepolisian yang ditetapkan dalam UU No. 2 Tahun 2002 tentang Kepolisian sebagai berikut:

1. Pasal 2 UU No. 2 Tahun 2002 fungsi Kepolisian adalah :

"salah satu fungsi pemerintahan negara di bidang pemeliharaan kemanan dan ketertiban masyarakat, penegak hukum, perlindungan, pengayoman, dan pelayanan kepada masyarakat".

2. Pasal 5 ayat (1) UU No. 2 Tahun 2002, "Kepolisian Negara Republik Indonesia merupakan alat negara yang berperan dalam memelihara keamanan dan ketertiban masyarakat, menegakkan hukum, serta memberikan perlingdungan, pengayoman, dan pelayanan kepada masyarakat dalam rangka terpeliharanya keamanan dalam negeri

3. Dalam rangka melaksanakan ketentuan- ketentuan dalam Pasal 5 UU No. 2 Tahun 2002, maka sesuai dengan Pasal 13 UU No. 2 Tahun 2002, Kepolisian Negara mempunyai tugas pokok:

a. memelihara keamanan dan ketertiban masyarakat;

b. Menegakkan hukum; dan

c. Memberikan perlindungan, pengayoman, dan pelayanan kepada masyarakat.

4. Pasal 14 UU No. 2 Tahun 2002, mengatur mengenai pelaksanaan tugas pokok sesuai yang dimaksud Pasal 13 UU No. 2 Tahun 2002, bertugas:

a. melaksanakan pengaturan, penjagaan, pengawalan, dan patroli terhadap kegiatan masyarakat dan pemerintah sesuai kebutuhan; 
b. menyelenggarakan segala kegiatan dalam rangka menjamin keamanan, ketertiban, dan kelancaran lalu lintas di jalan;

c. membina masyarakat untuk meningkatkan partisipasi masyarakat, kesadaran hukum masyarakat serta ketaatan warga masyarakat terhadap hukum dan peraturan perundang - undangan;

d. turut serta dalam pembinaan hukum nasional;

e. memelihara ketertiban dan menjamin keamanan umum;

f. melakukan koordinasi, pengawasan, dan pembinaan teknis terhadap kepolisian khusus, penyidik pengawai negeri sipil, dan bentuk-bentuk pengawasan swakarsa;

g. melakukan penyelidikan dan penyidikan terhadap semua tindak pidana sesuai dengan hukum acara pidana dan perundang-undangan lainnya.

Kenyataan tersebut di atas, menurut Barda Nawawi Arief ${ }^{14}$, bahwa Polri dalam menjalankan tugasnya berperan ganda baik sebagai penegak hukum (dibidang peradilan pidana) maupun sebagai pekerja sosial (sosial worker) pada aspek sosial dan kemasyarakatan (pelayanan dan pengabdian).

Selanjutnya, secara universal fungsi lembaga kepolisian mencakup dua hal yaitu pemeliharaan keamanan dan ketertiban (peace \& order maintenance) dalam penegakan hukum (law enforcement).

\section{Faktor Penghambat Kepolisian Dalam Melaksanakan Tugasnya}

Dalam rangka penegakan hukum Polri sangat dipengaruhi oleh faktor-faktor Penghambat Dalam Pelaksanaan fungsinya yang saling berkaitan dengan beberapa situasi dan kondisi masyarakat setempat.

Dalam praktik penegakan hukum, pihak Kepolisian menghadapi berbagai kendala, baik yang bersifat operasional maupun prosedural legal dan kemudian kendala ini tidak memberikan hasil yang optimal dalam upaya menekan kenaikan angka kriminalitas, bahkan terjadi sebaliknya. Semua hambatan-hambatan tersebut di atas bermuara pada model- model pendekatan yang dipergunakan yang harus didukung dengan profesionalisme, mental, pendidikan bagi setiap anggota Polri.

Berkenaan dengan hal tersebut, untuk mengetahui hambatan-hambatan terhadap peran dan fungsi yang dilakukan oleh kepolisian pada umumnya dan Polmas pada khususnya,

${ }^{14}$ Barda Nawawi Arief, Kebijakan Kriminal, Bahan Seminar, 2005, hal., 5 
dengan mempergunakan faktor- faktor umum yang mempengaruhi proses penegakan hukum ialah: ${ }^{15}$

1. Faktor hukumnya sendiri;

2. Faktor penegak hukum, yaitu pihak- pihak yang membentuk maupun menerapkan hukum;

3. Faktor sarana atau fasilitas;

4. Faktor masyarakat, yaitu lingkungan dimana hukum terasebut berlaku atau diterapkan;

5. Faktor kebudayaan, yaitu sebagai hasil karya, cipta dan rasa yang didasarkan pada karsa manusia dalam pergaulan hidup.

Dalam pembahasan ini penulis hanya membatasi tiga faktor yang paling dominan dan menentukan keberhasilan Polri sesuai dengan tujuan dalam sistem peradilan pidana.

\section{Faktor aparat/Petugas}

\section{a. Moral Penegak Hukum.}

Hubungan moral dengan penegakan hukum adalah menentukan suatu keberhasilan dalam penegakan hukum, sebagaimana diharapkan oleh tujuan hukum. Moral penegak hukum adalah salah satu aspek yang sangat menentukan dalam menjalankan peran dan fungsi Polri, ini dapat dilihat dengan adanya kasus korupsi yang melibatkan oknum kepolisian dalam kasus Koorlantas, beberapa kasus dugaan terorisme yang terjadinya penganiayaan terhadap orang yang diduga sebagai pelaku seperti kasus yang terjadi di Polres Poso.

\section{b. Keterampilan Penegak Hukum}

Keterampilan Polri tidak dapat mengikuti kemajuan teknologi yang begitu cepat dan umit, seperti pengetahuan tentang Teknologi Informasi, banking system kepolisian sangat terbatas jika dibandingkan dengan pengetahuan tersangkanya. Sehingga Polri sebagai penyidik tidak dapat melakukan penyidikan secara maksimal. Selama ini Polri didik dan terbiasa terhadap kejahatan yang bersifat konvensional. white collar crime merupakan tugas yang paling berat sementara sebagai seorang penyidik mempunyai beban tugas yang banyak karena porsonil kepolisian yang mempunyai tugas dalam hal penyidikan sangat terbatas, sehingga menimbulkan kelebihan beban tugas.

2. Faktor Fasilitas/Peralatan Pendukung Ketersedian fasilitas atau biasa disebut dengan istilah sarana dan prasarana pendukung proses penegakan hukum merupakan salah satu faktor penting yang ikut mempengaruhi bekerjanya fungsi hukum secara efektif

3. Kaidah Hukum atau Peraturan Itu Sendiri

${ }^{15}$ Soerjono Soekanto, Faktor-faktor yang Mempengaruhi Penegakan Hukum, op.cit, hal., 8. 
Berdasarkan kenyataan yang ada bahwa faktor hukum atau undang- undang itu sendiri merupakan faktor yang menjadi hambatan dalam pelaksanaan tugas.

\section{E. Kesimpulan}

1. Tugas dan Fungsi Kepolisian Sebagai Penegak Hukum Menurut UU Nomor 2 Tahun 2002 tentang Kepolisian Negara Republik Indonesia dapat dilihat pada Pasal 2 UU No. 2 Tahun 2002 mengenai fungsi Kepolisian. Fungsi kepolisian adalah "salah satu fungsi pemerintahan negara di bidang pemeliharaan kemanan dan ketertiban masyarakat, penegak hukum, perlindungan, pengayoman, dan pelayanan kepada masyarakat".

2. Faktor penghambat kepolisian dalam melaksanakan tugasnya dalam penegakan hukum yaitu :

a. Faktor hukumnya sendiri;

b. Faktor penegak hukum, yaitu pihak- pihak yang membentuk maupun menerapkan hukum;

c. Faktor sarana atau fasilitas;

d. Faktor masyarakat, yaitu lingkungan dimana hukum terasebut berlaku atau diterapkan;

e. Faktor kebudayaan, yaitu sebagai hasil karya, cipta dan rasa yang didasarkan pada karsa manusia dalam pergaulan hidup.

\section{F. Rekomendasi}

1. Sebaiknya masyarakat turut membantu tugas Kepolisian sehingga terjalin hubungan yang baik antara masyarakat dan Polri dan sehingga terhindar dari benturan yang dapat merugikan masyarakat dan citra Polri sendiri.

2. Sebaiknya polrinya sebagai penegak hukum dalam melaksanakan tugas dan wewenangnya tidak melakukan pilih kasih dalam menindaki pelaku tindak pidana sehingga dimata masyarakat citra polisi tidak buruk

\section{G. Daftar Pustaka}

Abdulkadir Muhammad. Hukum dan Penelitian Hukum. Cet. 1. PT. Citra Aditya Bakti. Bandung, 2004

B. Arief Sidharta (Penerjemah). Meuwissen tentang Pengembanan Hukum, Ilmu Hukum, Teori Hukum dan Filsafat Hukum. PT Rafika Aditama. Bandung 2009.

Barda Nawawi. Bunga Rampai Kebijakan Hukum Pidana. PT. Citra Aditya Bakti. Bandung. 2005. , Kebijakan Kriminal. Bahan Seminar. 2005. 
Baringbing Simpul, RE, Mewujudkan Supremasi Hukum, Pusat Kegiatan Reformasi. Jakarta. 2001.

Kansil. C.S.T. Pengantar Ilmu Hukum dan Tata Hukum Indonesia. Balai Pustaka. Jakarta. 1992.

Liliana Tedjosaputro. Etika Profesi Notaris; Penegakan Hukum. PT Bayu Indra Grafika. Yogyakarta. 1995.

Peter Mahmud Marzuki.Penelitian Hukum. Cet 2. Kencana. Jakarta. 2008.

Ph. Visser't Hoft. Penemuan Hukum (Judul Asli: Rechtvinding, Penerjemah B. Arief Shidarta. Laboratorium Hukum FH Universitas Parahiyangan. Bandung. 2001.

Satjipto Rahardjo. Penyelenggaraan Keadilan Dalam Masyarakat Yang Sedang Berubah, Masalah-Masalah Hukum, Nomor 1-6 Tahun X/10.

Soebroto Brotodirejo. Polri Sebagai Penegak Hukum. Sespimpol. Bandung.1989.

Soerjono Soekanto, Faktor-faktor yang Mempengaruhi Penegakan Hukum. Cet Kelima.

Rajawali. Jakarta. 2004.

, Efektivitas Hukum Dan Peranan Sanksi, Remaja Karya. Bandung. 2005

, Hukum Acara Pidana. Badan Penerbit Universitas Diponegoro. Semarang. 2006.

W.J.S.Poerwadarminta, Kamus Umum Bahasa Indonesia. PN Balai Pustaka. Jakarta. 1985.

Undang-undang Nomor 2 Tahun 2002 tentang Kepolisian Negara Republik Indonesia. 